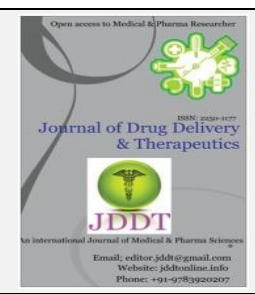

Research Article

Open $\bigcirc$ Access

\title{
Synthesis, Characterization, in vivo acute toxicity and superoxide anion scavenging evaluation of new isatin-hydrazone
}

\author{
Kamel Mokhnache*, Ahlem Karbab, Soraya Madoui, Hanane Khither, EL-Khamsa Soltani, Noureddine \\ Charef
}

Laboratory of Applied Biochemistry, University Ferhat Abbas Setif 1, 19000, Algeria

\begin{abstract}
A new isatin-hydrazone (I); $N^{\prime}-[(E)$-(5-bromo-1H- indol-3-yl) methylidene] pyridine-4-carbohydrazide was prepared from the condensation reaction of 5-bromo-1H-indole-3-carbaldehyde and the anti-tubercular drug; isoniazid, in the presence of acetic acid. The obtained hydrazone was identified and characterized by physico-chemical techniques such as melting point, IR, NMR, and mass spectroscopy. In addition, the acute toxicity was evaluated using mice. The antioxidant of I was evaluated against superoxide anion radical. Our biological resul ts indicate low toxicity of I at the high dose of $1000 \mathrm{mg} / \mathrm{kg}$, and high superoxide anion scavenging effect with inhibition percentage of $82.57 \%$ and IC50 138.78 $\mu \mathrm{g} / \mathrm{mL}$.
\end{abstract}

Keyword: hydrazone, toxicity, antioxidant, superoxide anion

Article Info: Received 03 Sep 2019; Review Completed 12 Oct 2019; $\quad$ Accepted 17 Oct 2019; Available online 15 Nov 2019

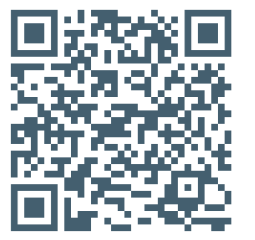

\section{Cite this article as:}

Mokhnache K, Karbab A, Madoui S, Khither H, Soltani E, Charef N, Synthesis, Characterization, in vivo acute toxicity and superoxide anion scavenging evaluation of new isatin-hydrazone, Journal of Drug Delivery and Therapeutics. 2019; $9(6): 12-16$ http://dx.doi.org/10.22270/jddt.v9i6.3656

*Address for Correspondence:

Kamel Mokhnache, Laboratory of Applied Biochemistry, University Ferhat Abbas Setif 1,19000, Algeria

\section{INTRODUCTION}

In pharmaceutical fields, indoles are heterocyclic compounds with high interest to human health. They have various pharmacological activities, such as antibacterial, antifungal, antihistaminic, analgesic, anticonvulsant, antioxidant, and anti-inflammatory [1]. In addition, 5-nitro$1 \mathrm{H}$-indole-2,3-dione-3-thiosemicarbazones and its derivatives exhibited in vitro a significant anti-tubercular effect against Mycobacterium tuberculosis H37Rv . Also, tricyclic and tetracyclic indole compounds demonstrate an excellent activity against human nasopharyngeal carcinoma (HONE-1) and gastric adenocarcinoma (NUGC-3) cell lines [2]. In recent years, a new concept of drug design was emerged for the development of new multifunctional drugs [3]. In this contest, indole derivatives are reported as a potential anti-inflammatory and antioxidant agents, for example; Indomethacin as an anti-inflammatory drug with high ability to reduce several free radical; such as reactive oxygen species (ROS) and reactive nitrogen species (RNS) [4]. For this reason, the objectives of this work are the synthesis of new hydrazone, the evaluation of their acute toxicity in mice model and the evaluation of their effect against one of the reactive oxygen species; superoxide anion.

\section{MATERIAL AND METHODS}

5-bromo-1H-indole-3-carbaldehyde (Aldrich), isoniazid (BHD chemicals Ltd)

\section{General procedure of hydrazone synthesis}

The reaction mixture containing $(0.005 \mathrm{~mol}, 1.1205 \mathrm{~g})$ of 5bromo- $1 H$-indole-3-carbaldehyde, $(0.005 \mathrm{~mol}, 0.6857 \mathrm{~g})$ of isoniazid and drops of acetic acid, the mixture was refluxed at $79{ }^{\circ} \mathrm{C}$ for $3 \mathrm{~h}$. after cooling, the precipitated powder was filtered and washed with hot ethanol and diethyl ether (Scheme 1). 
<smiles>O=Cc1c[nH]c2ccc(Br)cc12</smiles><smiles>[I-]</smiles><smiles>O=C(N/N=C/c1c[nH]c2ccc(Br)cc12)c1ccncc1</smiles>

Scheme 1. Synthesis of I

\section{Acute toxicity evaluation}

The acute toxicity was evaluated against mice (25-30g), in this assay the investigated hydrazone was administrated at the dose of 400,600 , and $1000 \mathrm{mg} / \mathrm{kg}$. Then, animal reactions were observed for 14 days. After this period, mice were scarified and plasma biochemical parameters were recorded.

\section{Superoxide anion scavenging assay}

$200 \mu \mathrm{L}$ of various concentrations of the tested compounds were mixed with $50 \mu \mathrm{L}$ of Nito-blue tetrazolium chloride, then $500 \mu \mathrm{L}$ of basic DMSO solution were added. After $5 \mathrm{~min}$, the absorbance was measured at $560 \mathrm{~nm}$ [5]. Inhibition percentage was calculated using the following equation:

$$
\begin{array}{r}
\text { Superoxide anion radical scavenging (\%) } \\
=100 \times(\mathrm{A} 0-\mathrm{A} 1) / \mathrm{Ac}
\end{array}
$$

Where $A_{0}$ : absorbance of the control and $A_{1}$ : absorbance in the presence of the tested compound.

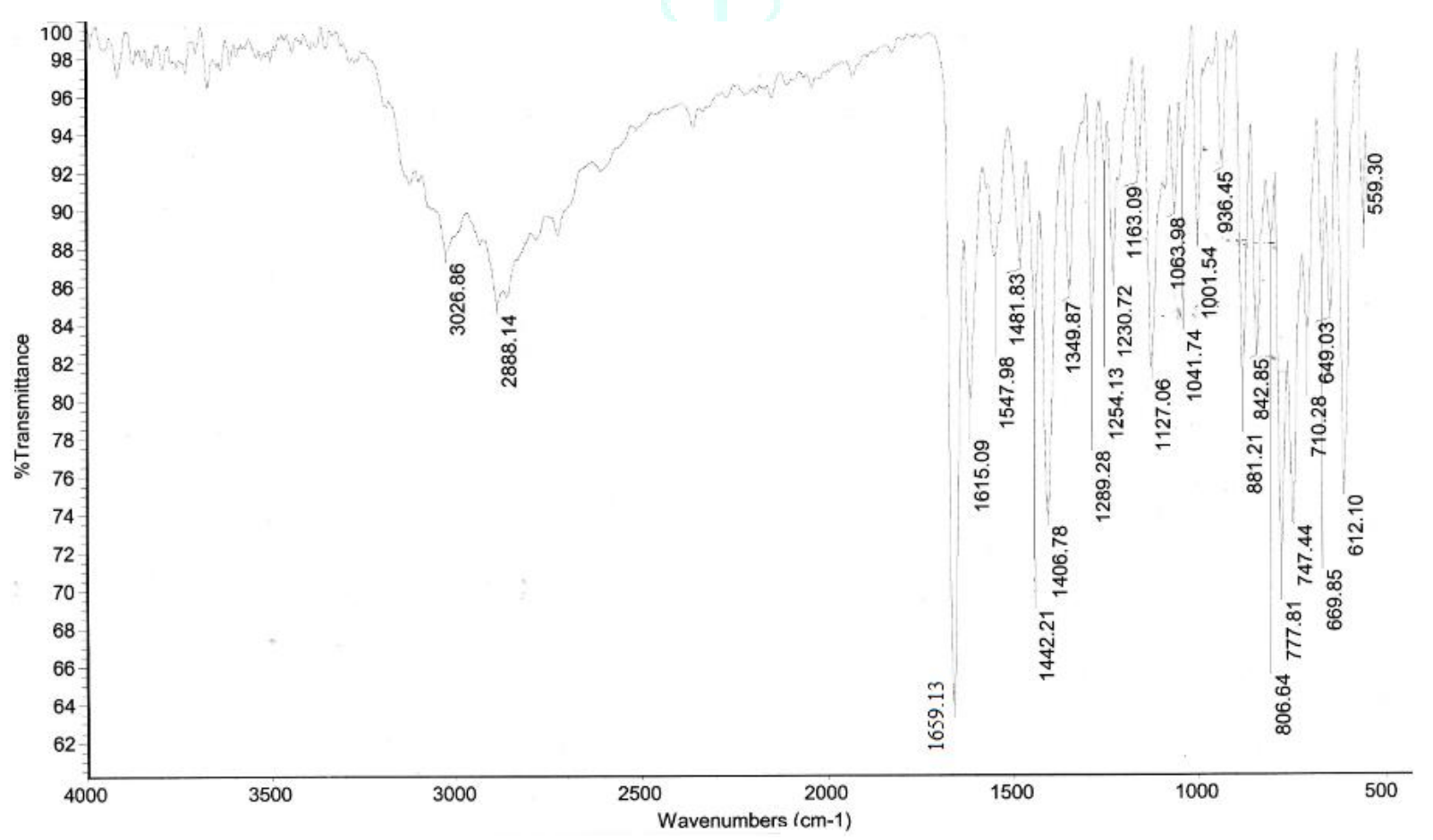

Fig. 1. FT-IR spectrum of I

High resolution mass spectra were achieved for the synthesized hydrazone I, by electrospray ion source coupled mass spectrometry (SM-ESI), followed by activation by the CID mode. Results obtained are depicted in Figures 2, which

\section{RESULTS AND DISCUSSION}

\section{Synthesis}

The Fourier transform infrared (FT-IR) spectra of the synthesized hydrazone demonstrated the characteristic absorption bands of the functional groups present in each compound as shown in Fig.1. The observed values of the characteristic absorption bands of these spectra and their interpretation are checked and discussed according to Silverstein [6] and Shriner [7].

The strong absorption bands at 1615 and $1659 \mathrm{~cm}^{-1}$ are assigned to the azomethine $(-\mathrm{C}=\mathrm{N}-\mathrm{NH})$ and the carbonyl groups of amide function $(\mathrm{O}=\mathrm{C}-\mathrm{NH})$, respectively. The band at $3013 \mathrm{~cm}^{-1}$ is attributed to the aromatic $(\mathrm{C}-\mathrm{H})$ stretching vibration, whereas the one at $3196 \mathrm{~cm}^{-1}$ is due to $(\mathrm{N}-\mathrm{H})$ symmetrical stretching vibration of secondary amide. 


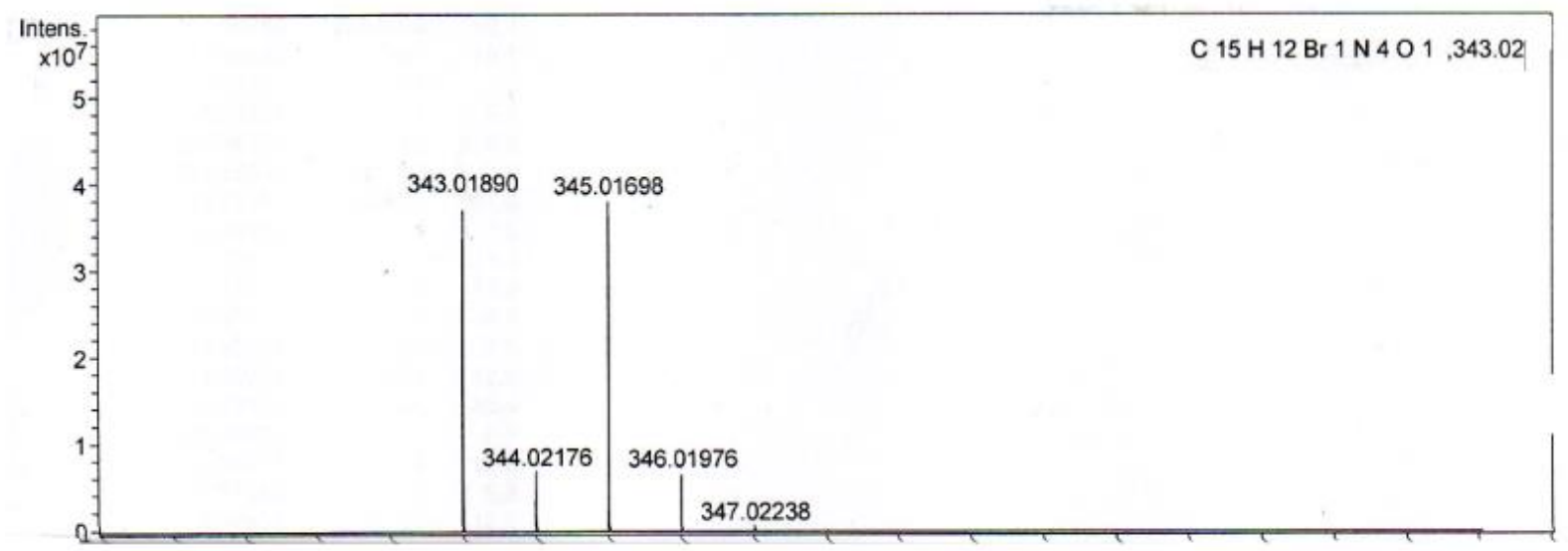

Fig. 2. High resolution mass spectrum (HRMS) of I

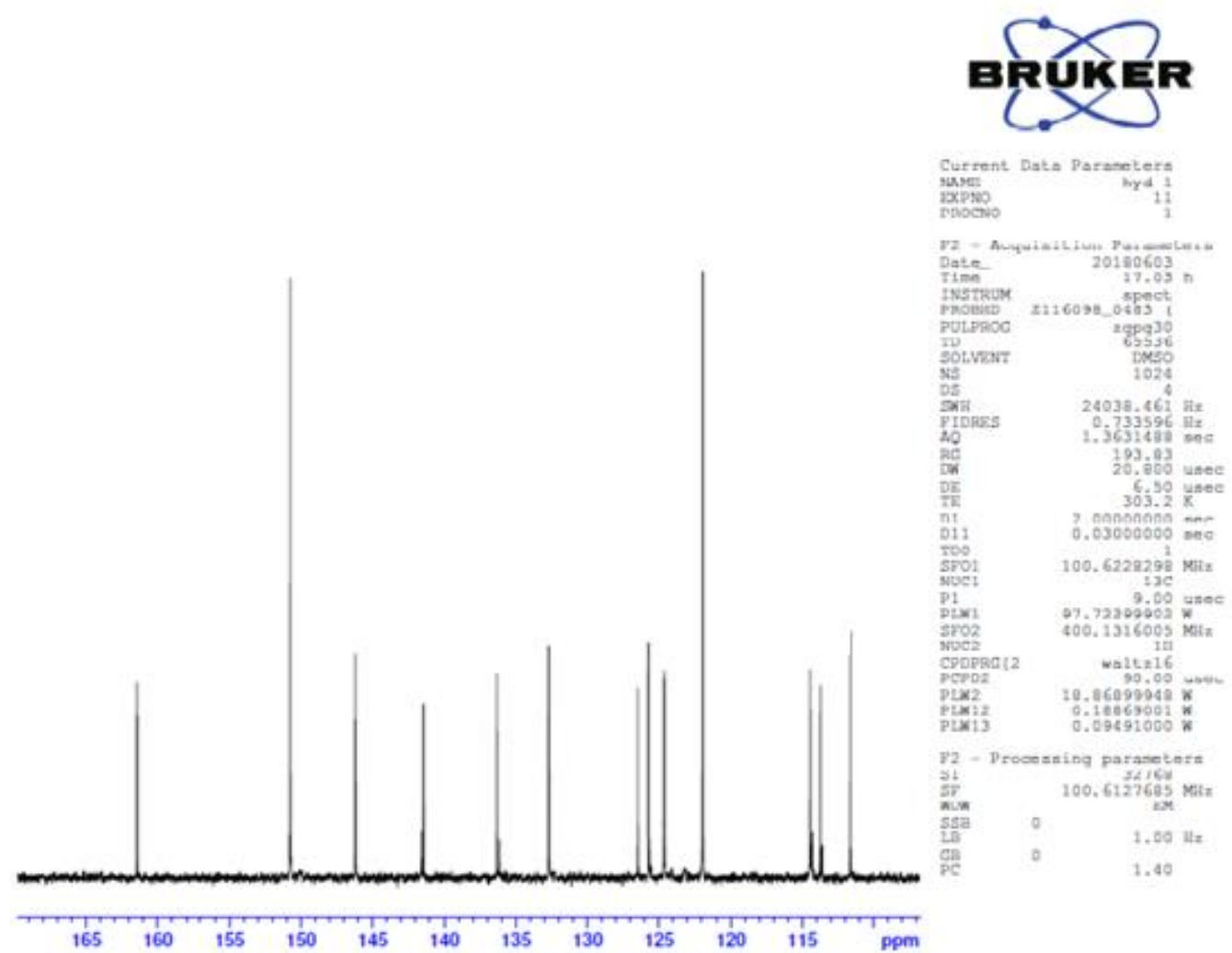

Fig. 3. ${ }^{13} \mathrm{C}$-NMR spectrum of $\mathbf{I}$; (DMSO- $\mathrm{d}_{6}$ )

\section{Acute toxicity evaluation}

Acute toxicity determination plays fundamental roles in drug design and in eco-toxicological studies [8]. In acute toxicological testing, the tested compounds were administered at different dose levels, and the effect was observed for 14 days [9]. For this reason, $1000 \mathrm{mg} / \mathrm{kg}$ was selected as the dose for in vivo acute toxicity evaluation.

\section{Behavioral observations and mortality patterns}

In vivo acute toxicity evaluation of $\mathbf{I}$ demonstrated no mortality at the dose of $1000 \mathrm{mg} / \mathrm{kg}$ after $24 \mathrm{~h}$ of drug administration, and without abnormal actions over 14 days.

\section{Body weight estimation}

Mice body weight was measured each seven days of experiment and results (Fig. 4) indicate an increase in the body weight of both treated groups compared with the control. 


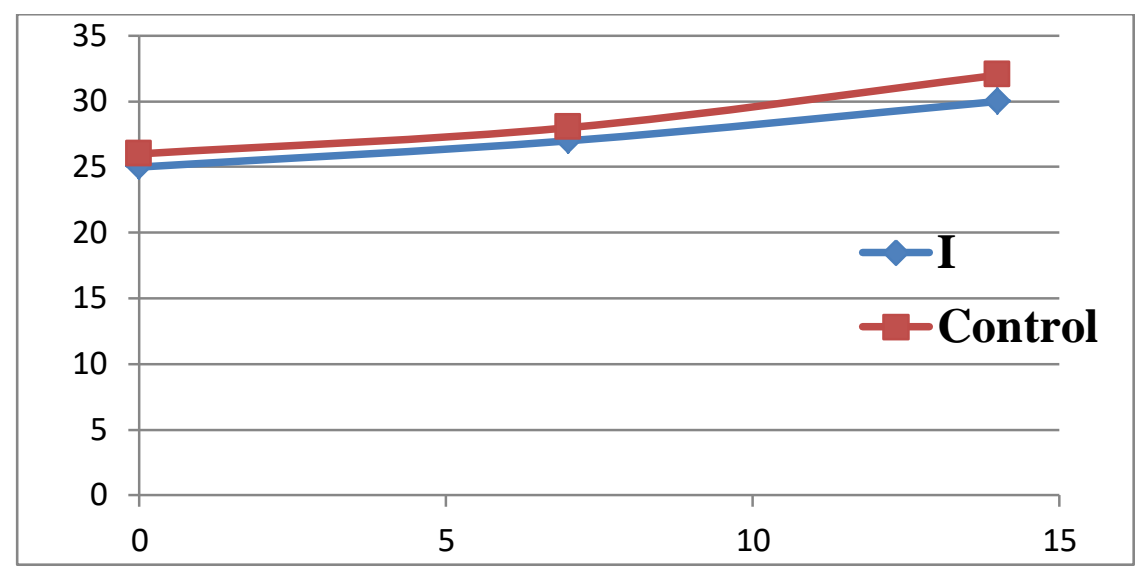

Fig. 4. Development of mice body weight; Values expressed as mean $\pm S E M, n=5$ animals /group.

\section{Biochemical parameters}

Biochemical analyses were conducted at the end of the experiments. Plasma biochemical parameters including urea, creatinin, albumin, calcium, protein, cholesterol, uric acid, AST, ALT, and ALP, results are given in Table 1. AST and ALT are the most commonly used biochemical markers of liver injury [10]. Results revealed that ALT decreased significantly by 2.3 fold, compared to the control group when mice were treated with I. Similarly, levels of AST decreased significantly by 1.6 fold, compared to that of the control group.

Table 1. Biochemical parameters of control and mice treated with I

\begin{tabular}{lcc}
\hline Parameters & Control & Hydrazone (I) \\
\hline ALP (UI/l) & 321.25 & 206 \\
\hline AST (UI/l) & 132.1 & 79 \\
\hline ALT (UI/l) & 34.55 & 14.5 \\
\hline Urea (g/l) & 0.69 & 0.97 \\
\hline Creatinin (mg/L) & 21.95 & 23.25 \\
\hline Uric acid (mg/L) & 13.20 & 15.85 \\
\hline Cholesterol (g/L) & 1.01 & 2.02 \\
\hline Albumin (g/L) & 18.96 & 42.13 \\
\hline Protein (g/L) & 58.44 & 87.23 \\
\hline Calcium (mg/L) & 1.67 & 1.25 \\
\hline
\end{tabular}

\section{Superoxide anion scavenging effect}

Reactive oxygen species (ROS) are damaging agents, which cause several pathologies in human body [11]. Superoxide anion radical $\left(\mathrm{O}_{2} \cdot-\right)$ is one of these harmful species, was considered as the principle source of ROS [12]. In this study, I was investigated for their antioxidant effects using superoxide anion scavenging assays. Our findings, (Fig. 5) demonstrate high superoxide anion scavenging effect with inhibition percentage of $82.57 \%$ and $\mathrm{IC}_{50}$ of $138.78 \mu \mathrm{g} / \mathrm{mL}$.

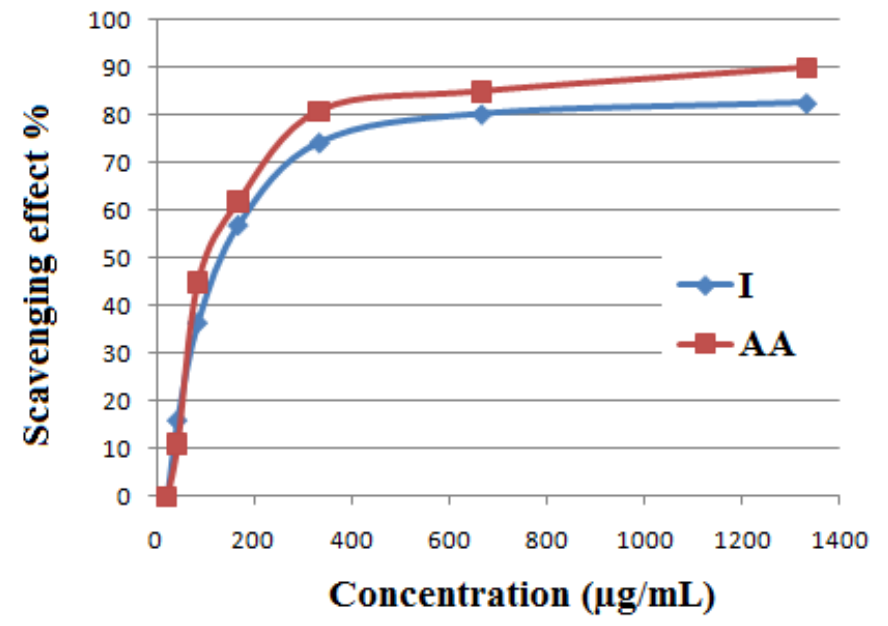

Fig. 5. Superoxide anion scavenging effect of I 


\section{CONCLUSION}

The synthesized hydrazone is an indole derivative has high superoxide anion scavenging effect, with low acute toxicity. We conclude that this hydrazone could be a safe antioxidant agent.

\section{ACKNOWLEDGEMENTS}

This work was supported by the Algerian Ministry of Higher Education and Scientific Research (MESRS), and the Thematic Agency for Research in Health Sciences (ATRSS)

\section{REFERENCES}

[1] Singh TP, Singh OM. Recent Progress in Biological Activities of Indole and Indole Alkaloids. Mini-Rev Med Chem. 2018; (18) 9-25

[2] Sharma V, Kumar P, Pathaka D. Biological Importance of the Indole Nucleus in Recent Years: A Comprehensive Review. J Heterocyclic Chem. 2010; (47) 491-502

[3] Demurtas M, Baldisserotto A, Lampronti I, Moi D, Balboni G, Pacifico S, Vertuani S, Manfredini S, Onnis V. Indole derivatives as multifunctional drugs: Synthesis and evaluation of antioxidant, photoprotective and antiproliferative activity of indole hydrazones. Bioorg Chem. 2019; (85) 568-576

[4] M S. Estevão, L.C. Carvalho, D. Ribeiro, D. Couto, M. Freitas, A. Gomes, L.M. Ferreira, E.Fernandes, M.M.B. Marques, Antioxidant activity of unexplored indole derivatives: Synthesis and screening, Eur J Med Chem. 2010; (45) 48694878.
[5] Gowri R, Madhavan V, Evaluation of antioxidant activity of ethanolic extract of Sphaeranthusamaranthoides Burm.f, Inter J Drug Dev Res. (5); 2013 320-329.

[6] Silverstein RM, Webster FX, Kiemle DJ, "Ch. 2: Infrared spectrometry", In: "Spectrometric Identification of Organic Compounds", 7th edition, John Wiley \& Sons, Inc., USA, 2005, 72-126.

[7] Shriner RL, Hermann CKF, Morrill TC, Curtin DY, Fuson RC,"Ch. 7: Infrared spectrometry", In: "The systemic identification of organic compounds", 8th edition, John Wiley \& Sons, Inc., USA, 2004, p. 194-227.

[8] Wang Y., Ning Z.H., Tai H.W., Long S., Qin W.C., Su L.M., Zhao Y.H., Relationship between lethal toxicity in oral administration and injection to mice: Effect of exposure routes, Reg Tox Pharm. 2015; (71) 205-212.

[9] S. Parasuraman, Toxicological screening, J Pharm Pharmacother. 2011; (2) 74-79.

[10] Giannini EG, Testa R, Savarino V, Liver enzyme alteration: a guide for clinicians, Can Medical Asso J. 2005; (172) 367-379.

[11] Khither H, Sobhi W, Khenchouche A, Mosbah A, Benboubetra M. In-vitro Antioxidant Effect of Thymoquinone. Ann Res Rev Biol. 2018; (25) 1-9.

[12] H. Tao, J. Zhou, T. Wu, Z. Cheng, High-throughput superoxide anion radical scavenging capacity assay, J Agr Food Chem. 2014; (62) 9266-9272. 